\title{
Dossı̂̀ | A IMAGEM FOTOGRÁFICA DO COTIDIANO:

\author{
significado e informação no jornalismo
} \\ Copyright (C) 2011 \\ SBPJor / Sociedade Brasileira de Pesquisa em Jornalismo \\ ATÍLIO AVANCINI \\ Universidade de São Paulo
}

\begin{abstract}
RESUMO O fundamento teórico deste artigo são os princípios conceituais dos franceses Philippe Dubois (baseado no livro O Ato Fotográfico), Roland Barthes (livro A Câmara Clara) e Henri Cartier-Bresson (texto $O$ Instante Decisivo). Seus textos de leitura são referência para o objetivo de proporcionar uma compreensão dos significados das fotografias na narrativa jornalística. É um debate crítico sobre a presença da imagem fotográfica no jornalismo, reorganizando conhecimentos diante da fragilidade conceitual, que passa a fotografia digital como documento e informação. Uma das ideias a ser considerada se vincula na hipótese de que hoje, na reconfiguração dos estudos fotográficos do cotidiano urbano (crise de identidade gerada pela tecnologia digital), o sentido se faz mais importante do que a imagem pela imagem.
\end{abstract}

Palavras-Chave: Comunicação. Jornalismo visual. Reportagem fotográfica. Vida urbana. Significação na fotografia.

\section{INTRODUÇÃO}

Desde o seu surgimento, a fotografia vem gerando textos visuais sobre retratos de pessoas, vida cotidiana, cidades, povos aborígenes, paisagens, mundo animal, botânica, objetos industrializados, dentre outros. E sempre de maneira estimulante à imaginação e às interpretações. A fotografia possibilitou ver a realidade de modo diferenciado e acrescentou ineditismo à linguagem visual. "Com isso a percepção do mundo se tornou mais aprofundada e complexa. Embora a fotografia - e o cinema - não revelem nada do mundo no sentido literal, contribuem educativamente para o ver melhor" (AUMONT, 1995, p. 276).

Em quase dois séculos de existência, a superfície sensível da fotografia passou pelo betume, metal, papel, vidro e acetato (filme). Hoje, a paisagem teórico-prática se alterou com a fotografia digital. Nem tudo ficou obsoleto, embora o olhar contemporâneo não seja o mesmo (e nem poderia ser de outra forma). Diante desses fatores como atualizar a questão da fotografia - ligada à tradição de documento - e a sua aproximação com o real? 
É sobre esta visão documental que este artigo destaca os conceitos elaborados pelos autores de referência Philippe Dubois, Roland Barthes e Henri Cartier-Bresson, relacionando-os e confrontandoos com os processos das novas tecnologias. Desse modo, será possível redimensionar o objeto fotografia, à luz do universo teórico da tecnologia digital, gerado pela crise da fotografia na comunicação social como informação. O estudo tem como objetivo produzir reflexões teóricas, como contribuição para a cidadania e a compreensão da vida urbana contemporânea, em relação à proeminência que a imagem digital vem assumindo nas últimas décadas no contexto do fotojornalismo.

Redimensionar a questão do fotográfico é analisar o desenvolvimento do enfoque humanista nos processos analógico ou digital, buscando a importância da conscientização do ver na comunicação social. Ou questionar o ato fotográfico como rastro ou vestígio deixado pela existência de algo físico-material, buscando uma expansão no sentido de reconstrução da realidade. A hipótese de trabalho se vincula na reconfiguração dos estudos fotográficos - crise de identidade gerada pela tecnologia digital -, em que os sentidos se fazem mais importantes do que a imagem pela imagem.

\section{Sombra petrificada}

A invenção da fotografia foi o resultado da conjunção de dois fatores preliminares e distintos: ótico (dispositivo de captação da imagem) e químico (dispositivo de sensibilização à luz de certas substâncias à base de sais de prata). A fotografia instalou o hábito da percepção imóvel da realidade sob o prisma do testemunho em recorte espaço-temporal. Ou seja, desde o seu surgimento ela atua como tecnologia da informação e memória.

Portanto a imagem fotográfica vem sendo utilizada como representação especular do real - com legitimidade de documento -, dentro da premissa de ter recortado um instante único e isolado uma porção de extensão do visível. Isto é, um fragmento de determinado momento (tempo) em determinado lugar (espaço). A fotografia, em síntese, retém um traço da ação da luz. Assim, a fotografia analógica é metaforicamente considerada "sombra petrificada" (DUBOIS, 1994, p. 139), deixando rastros - vestígios materializados - nos grãos de prata da superfície sensível no momento-traço do clique.

O século XIX tinha uma concepção da fotografia que chamo de discurso da mimese, um conceito daquela época. As imagens eram vistas como uma reprodução do mundo como ele é. Era 
uma noção icônica. É certo que o século XIX foi marcado por essa visão de semelhança, mas ela não desapareceu, é ainda uma crença contemporânea, um ponto de vista hoje muito frequente. Com esforço, alguns teóricos do início do século XX demonstraram que a imagem fotográfica não era um espelho neutro, mas um instrumento de interpretação do real. Alguns exemplos dessa transposição foram percebidos: o preto-e-branco contrastando com a realidade em cores, a imagem fixa e o mundo constantemente mudando, a imagem bidimensional advinda da realidade tridimensional, o puramente visual excluindo qualquer outra sensação auditiva, olfativa, tátil ou gustativa. Portanto a fotografia não é como o mundo, ela transforma o mundo (DUBOIS, 2003).

De fato, no final do século XIX foi possível contradizer a tese de que a essência da fotografia era uma imagem fiel da realidade (o argumento para esta visão da "verdade" foi a inauguração que a fotografia proporcionou de uma imagem formada pela máquina sem a intervenção da mão humana). Assim, com a compreensão da fotografia como transformação da realidade, a não aceitação da imagem mecânica perfeita pôde ser bastante explorada no decorrer do século XX, tanto na produção fotográfica quanto na construção de significados.

\section{Em três tempos}

O referente, ou seja, a coisa real a ser fotografada - homem, animal, paisagem -, está ligado fundamentalmente ao ato que constitui o fazer ver uma imagem. É como dizer que toda a fotografia anuncia o seu sujeito. A fotografia como signo indicial pressupõe - pensando o signo como a representação de algo gerador de significados e o índice como a lógica do resquício deixado por algo - a existência material de alguma coisa diante da câmera, derivando daí sentidos múltiplos. É por isso que o ato fotográfico surge a partir do referente da imagem.

Uma possibilidade de lidar com os princípios sígnicos da fotografia é a fundamentação em três tempos, sugerida pelo americano Charles Sanders Peirce (DUBOIS, 1994, p. 27). A regência ternária é subentendida pelo ícone (semelhança), símbolo (visão histórica, convenção cultural e forma plástica) e índice (conexão real com o referente). A fotografia como construção sígnica, pautada por três movimentos simultâneos, abarca também a ideia da tese, antítese e síntese. Nesse caso, a síntese (índice) não entra em contradição com os outros termos, não havendo, portanto, oposição, entre o ícone e o símbolo.

A questão do ícone serve de base para a compreensão da fotografia, relacionada à analogia e identidade. Ou seja, em conformidade com o referente ligado ao real. É pela semelhança que, via comparação e confrontação, se busca compreender a imagem. E como lidar com a 
questão do símbolo diante da perspectiva histórica, cultural e estética? Philippe Dubois responde, apontando para a fotografia de capa do jornal Folha de S. Paulo, na imagem de dois candidatos à prefeitura da cidade de São Paulo em debate político, produzida nos estúdios de um canal de televisão, em outubro de 2000.

Reparo a cor do fundo da fotografia em vermelho. É pelo saber cultural que posso relacionar o vermelho a uma cor politicamente identificada aos movimentos de esquerda. Além disso, a cor vermelha é um pensamento como vermelho, uma ideia em si, uma dimensão ou saber estético. Não é só um saber sobre o conteúdo, mas também sobre a sua forma expressiva (DUBOIS, 2000).

Por último o índice, que faz parte da lógica do resquício de objetos, diante da materialidade (ou corporalidade) das coisas, registrados na superfície sensível. Assim, a comprovação do fato acontecido ocorre pela conexão entre o índice e o referente. Uma qualidade única da fotografia. Portanto da ordem do traço, da marca, do rastro, do registro. A fotografia pertence a uma categoria de signos diferenciados do desenho, pintura, escultura ou texto escrito, que operam basicamente entre o ícone e o símbolo.

Na tríade da construção sígnica, há ainda a produção discursiva (fotográfica), que apresenta três elementos de linguagem: o antes (a concepção da imagem a ser produzida pelo emissor-fotógrafo), o clique fotográfico (o momento-traço em torno da mensagem, exclusivo da câmera) e o depois (a contemplação da fotografia pelo receptor-leitor). O antes e o depois fotográficos envolvem tanto o ícone, quanto o símbolo. Isto é, ao produzir e ler uma imagem, o ícone e o símbolo estão incorporados.

Faz sentido unir esses elementos do circuito de comunicação ao pensamento de Roland Barthes, que designa para cada fase da função ternária um termo de origem grega: o antes ligado ao Operator (fotógrafo), o clique ao Spectrum (referente) e o depois ao Spectator (leitor). Vale ressaltar que o pensamento de Barthes prioriza a relação do Spectator diante da imagem fotográfica.

Eis-me pois eu próprio como medida do "saber" fotográfico. O que sabe o meu corpo da Fotografia? Notei que uma foto pode ser o objeto de três práticas (ou de três emoções, ou de três intenções): fazer, experimentar, olhar. O Operator é o fotógrafo. O Spectator somos todos nós que consultamos nos jornais, nos livros, álbuns e arquivos, coleções de fotografias. E aquele ou aquilo que é fotografado é o alvo, o referente, uma espécie de pequeno simulacro, de eidôlon emitido pelo objeto, a que poderia muito bem chamar-se o Spectrum da Fotografia, porque esta palavra conserva, através da raiz, uma relação com o "espetáculo" (BARTHES, 1981, p. 23). 


\section{Leitura de sentidos}

Como fazer a leitura de significados de uma imagem fotográfica que representa o seu referente? Há na fotografia diferença entre a existência (ligada aos fatos) e a significação (ligada aos sentidos)? Ou, como diz Roland Barthes, há o "isto-foi" - associado à "existência real do seu referente" - e, ligeiramente afastado, o "isto-quer-dizer" (BARTHES, 1981 , p. 1 10). A fotografia não sendo lida pelo ato de significar, volta a cair na condição de coisa, isto é, naquilo que repousa em desconhecimento e ignorância (MERLEAU-PONTY, 2006, p. 172).

Quando do seu surgimento, a fotografia foi logo aceita como fonte documental e informativa, pois a pintura estava mais ligada à arte. Dentro da perspectiva de que os pintores atuavam com a visão interpretativa do mundo, surgiu o método de Irwin Panofsky (ligado ao Spectator) para compreender os significados das pinturas. A partir do momento em que caiu por terra o preceito de que "a fotografia não interpreta, não seleciona, não hierarquiza" (DUBOIS, 1994, p. 32), tal método foi também utilizado pela fotografia e pelo cinema.

Descrição, análise cultural, interpretação. São as três premissas básicas de Panofsky, que permitem ao leitor interagir histórica e culturalmente com a imagem fotográfica, para alçar significados e informações para a construção do saber. Voltada, neste caso, ao discurso jornalístico, a descrição deve ser capaz de criar uma narrativa verbal da representação especular. É conhecida como pré-iconografia, ou significação primária, consistindo no reconhecimento e na identificação do que é visto, dos objetos visualmente registrados. Trabalha com o conteúdo físico (a noção icônica do século XIX). Deve haver nesta leitura imagética a preocupação com o detalhe para varrer (como o scanner) o máximo de informação possível. Opera como gesto-base, e é recomendável um olhar bem completo.

Depois das identificações primeiras, agora é preciso analisar de qual rede cultural a fotografia opera. E fazer conexões para elucidar os acontecimentos, criando uma tessitura narrativa a partir das premissas do jornalismo (o quê, quem, como, onde, quando, por que, por isso). Ou seja, as relações que se colocam em movimento diante do reconhecimento descritivo. A análise cultural trabalha com o objetivo e o subjetivo (a noção simbólica do século XX), baseada nas imagens dinâmicas do saber histórico e fixas do saber cultural. É conhecida como iconografia (escrita do ícone) ou significação secundária, fundamentada na história e na cultura (costumes típicos da sociedade, senso comum, valores transmitidos coletivamente). 
Considera-se também como relevante: autor, lugar, data, câmera fotográfica, lente, personagem, cenário, cor predominante, linha, forma, fonte de luz, foco, composição, fotometragem (asa/ iso), velocidade, diafragma. Além disso, é possível surgir informações outras pelas referências exteriores à imagem. Por exemplo, o jornal ou revista (impresso ou eletrônico), lugar editorial da fotografia aplicada, resultando sentidos novos à imagem. E ainda outros contextos de significados advindos da linguagem escrita, gráfica ou fotográfica, que podem operar simultaneamente com a imagem estudada. Por exemplo, a foto de capa de um jornal interage com a manchete, a legenda, as chamadas, os textos, as outras fotografias, os infográficos, as charges, as publicidades e até com o próprio nome do jornal.

$\mathrm{Na}$ análise cultural há uma exposição de ideias culturais para além do descritivo da imagem. Por exemplo, no Ocidente a pomba branca pode significar a paz. O automóvel importado e conversível, entendido como riqueza e soberba. O político, assimilado como poder, firmeza de atitudes ou maldito. O jogador de futebol, visto como mito da torcida. O artista, percebido como rebelde, ativista politico ou romântico. Ou a mulher, compreendida como criação, fertilidade, proteção, beleza, sedução, família, sensibilidade e intuição.

Parece claro compreender que entre o leitor ocidental e o oriental, numa mídia tradicional ou diferenciada, há diferentes perspectivas culturais. Roland Barthes, voltado para a compreensão das linguagens, considera outros sentidos que devem ser acrescidos às premissas históricas e culturais de Panofsky. São as imagens dinâmicas do saber subjetivo, transformadas em significados, na interpretação das mensagens codificadas pelo leitor comum.

Construir sentido em leitura é fazer interagir as experiências de linguagem do leitor e seus conhecimentos de mundo com a matéria-prima que possui diante dos olhos, por meio dos dados formais e contextuais desta última (PIETRARÓIA, 2001, p. 25).

Cognitivo, afetivo, estético e técnico. São os quatro elementos, ou dimensões, que contribuem para dar sentidos mais amplos aos dados históricos e culturais. O cognitivo está ligado ao conhecimento de mundo, à capacidade histórica e informativa, à pressuposição jornalística (leitor bem informado). O afetivo se articula pelos interesses, desejos, atitudes ou sensações. O estético interage via gosto pelas formas, pensamento visual, identificação gráfica e/ou plástica. O técnico lida com os conhecimentos fotográficos e gráficos.

Por último a interpretação. Aqui, de fato, a noção da visão crítica se 
faz mais presente. E, portanto, pressupõe riscos. Por isso é prudente uma interpretação breve e sintética, recorrendo inclusive à eventual utilização de palavras-chave e da linha imaginária principal da fotografia. É conhecida como iconologia (estudo do ícone) ou significação essencial, fundamentada no argumento do não mostrado. É preciso tentar construir algo com certa solidez, mas o pressuposto nem sempre é muito seguro e estável.

Para uma interpretação de imagens pode haver sempre outra, até uma terceira ou quarta. As fotografias são sempre suscetíveis a multi-interpretações. Portanto não é a mesma coisa da análise cultural. Nesta, estamos todos razoavelmente de acordo. Na interpretação começamos a enxergar coisas mais sutis e propor hipóteses sobre valores de alguns sinais. É bastante aleatório. E nada é assim tão evidente, já que tudo é muito discutível (DUBOIS, 2000).

\section{Textos imagéticos e verbais para lembrar os seres amados}

Roland Barthes (1915-1980) assumiu a literatura como referência aos estudos da fotografia. O movimento conhecido como Estruturalismo constituiu, provavelmente, o auge da denúncia ao efeito realidade, tanto na fotografia como no cinema. Nas análises semiológicas de Christian Metz e Roland Barthes, a fotografia foi vista como informação e construção, incluso a argumentação (retórica). Vale ressaltar que o livro A Câmara Clara, de Barthes, é posterior à sua fase Estruturalista, quando assume o prazer pessoal pelo texto (escrito ou visual), dado ligado à psicanálise, fundamental para o debate crítico sobre a fotografia como linguagem na comunicação de massa.

A comunicação se dá quando o texto é capaz de atingir, modificar e absorver o leitor de forma ativa. Barthes recupera o sentido da narrativa pelo gosto da leitura e pelo reconhecimento do outro. "Eu jogo sem ilusão, mas com a alegria esfuziante do artista. Nesse encaminhamento de amador, repleto de motivos, sem dúvida, intervém talvez o prazer de um tipo de conforto artesanal" (BARTHES, 2003).

Depois de descobrir o Japão em três viagens sucessivas (de 1966 a 1968), Barthes se volta ao prazer do artista amador (ler, escrever, pintar). O Japão oferece o exemplo de uma civilização em que tudo é imagem, sem jamais devolver um significado último. A ritualização da vida cotidiana, o teatro noh, o shodo (caligrafia), o suibokuga (pintura) e o haiku (haikai) são meios de sair dos muros simbólicos do Ocidente.

Ir a um kissa-ten (salão de chá ou cafeteria) para uma conversa informal entre amigos é, de certa forma, como produzir shashin, fotografia (literalmente, reflexo da realidade ou reflexo da verdade). Há um termo para a arte do chá, ichigo-ichie, que bate com o momento decisivo da fotografia: encontro único na vida. Ou, também, um tesouro a cada encontro, que nunca mais 
Nos anos 1960, publica seus primeiros textos ligados à Semiologia para estudar a fotografia, se propondo a pesquisar seus códigos. Com isso, percebe a linguagem escrita como prática clandestina que pode, de certo modo, abalar o sujeito e dissolvê-lo no espaço da página. O prazer do texto literário é um exercício de apropriação para recolocar o autor no centro da enunciação. Por isso em suas últimas obras, além de discorrer sobre os valores culturais do sujeito leitor, passa a incluir vivências no campo da subjetividade. Sua ideia: se libertar da vertente teórica do Estruturalismo e desconstruir formalizações acadêmicas e dogmáticas.

Desde o falecimento de sua mãe, em outubro de 1977, sua vida é consagrada à pesquisa de temáticas voltadas para o amor e a morte. Os cursos no Collège de France, em Paris, intitulados "A preparação do romance", inspiram o autor para a sinceridade dos afetos e das ideias, um meio de transformar o sofrimento em transcendência. Para Barthes, a noção de escritor e leitor é reconhecidamente longe de ser estável.

A fotografia anônima, "Roland Barthes com a sua mãe", registrada em Baiona/Marrac (França) em 1923, evidencia o menino de oito anos com traje escolar, posando no colo de sua mãe Henriette Barthes (BARTHES, 1977, p. 9). E retrata o garoto inseguro, tendo perdido o pai na I Guerra Mundial, acolhido pela proteção materna. Rostos colados, olhares penetrantes, braços entrelaçados: a imagem nada esconde, mas também nada fala. O segredo está em desvendar o óbvio: o amor profundo entre ambos. Mas para Barthes o caminho obtuso é desvendar o objeto (no caso, a fotografia) capaz de refletir o amor ausente.

\section{Da câmara escura à câmara clara}

Mais que uma reflexão sobre a fotografia, A Câmara Clara (La Chambre Claire, 1980) é uma mediação sobre a perda do amor e a retomada do tempo perdido. A última obra de Barthes é escrita à sombra de Marcel Proust (1871-1922). E o texto-imagem, como o texto-escrito, faz lembrar os seres amados. Fotografia e texto escrito não são garantias de verdade, mas a fotografia - diferentemente da escrita e da pintura atesta e legitima a existência do ocorrido pela presença do referente.

Em A Câmara Clara, a máxima de que a "fotografia é inclassificável" foi uma alusão aos parâmetros da linguagem escrita, cujo discurso mais seguro poderia ser mais bem aprofundado (BARTHES, 1981, p. 17). Comparar a fotografia à realidade não seria certamente o melhor caminho para descobrir a sua natureza. Para o escritor, não é a realidade que a 
fotografia acessa, mas imagens. A fotografia é invisível, artificiosa, cega, ilusão, quando igualada à realidade. E, além disso, não tem marca própria. A fotografia, portanto, deveria ser desmitificada como garantia da verdade.

No ensaio literário A Câmara Clara, Barthes apresenta um trabalho dotado de método para criar conceitos. O livro, escrito entre 15 de abril e 3 de junho de 1979, expressa a poética da ausência, divagando sobre a leitura não linear da fotografia (ser exterior) e sobre a morte de sua mãe (ser interior). Barthes, em paralelo com a mensagem fotográfica, redige um texto verbal fragmentado, descontínuo, interpretativo e expresso em primeira pessoa do singular. E assume a perspectiva do leitor (Spectator), convidando-o para adentrar na câmera fotográfica no momento do clique. Primeiramente decifra o objeto fotografia para conscientizar os princípios organizadores e constituintes dessa linguagem. E, ao mesmo tempo, traz a sua essência pessoal: especula impressões sobre a imagem "Jardim de Inverno", produzida por um fotógrafo anônimo e amador, em 1898. O retrato é a foto de sua mãe, quando havia completado cinco anos de idade. Ou seja, estudar a fotografia é descobrir os sentidos de quem somos e do que vemos (lemos).

Entretanto, há uma constante coexistência sem a qual não existiria a fotografia: a presença indissociável do algo representado, o referente (Spectrum), que adere à imagem fotográfica. Ele cita o exemplo de que "um cachimbo é sempre um cachimbo, infalivelmente" (BARTHES, 1981 , p. 18). Assim, contrapõe uma concepção fundante das artes plásticas percebida pelo pintor surrealista belga René Magritte (18691967) que, ao representar um cachimbo, escreveu na tela "ceci n'est pas une pipe" (isto não é um cachimbo). A fotografia, de outro modo, garante como representação o passado testemunhal de determinado objeto, e é "certificado de presença" que autentifica algo. "A vidência do fotógrafo não consiste em ver, mas em estar lá" (BARTHES, 1981, p. 122).

\section{Capturar a essência humana}

Cansados dos retratos da classe dominante ou das imagens de dor nos periódicos ilustrados, durante a Guerra Civil Espanhola ou a II Guerra Mundial, os fotógrafos humanistas, que tinham Paris como epicentro criativo, exaltaram a vida - e a paz -, produzindo imagens de anônimos do cotidiano urbano. As fotos estavam mais próximas de capturar a essência humana do que as imagens objetivas da imprensa. André Kertész, Brassaï (Gyula Halasz), Edouard Boubat, Henri CartierBresson, Josef Koudelka, Marc Riboud, René Burri, Robert Doisneau, Willy Ronis e Pierre Verger foram exemplos desse movimento. 
Os fotógrafos inauguraram uma era na qual as ações do dia a dia foram registradas por um olhar pessoal: eventos e manifestações políticas, figuras e casais pitorescos, retratos de artistas e intelectuais, tradições culturais e paisagens urbanas, reportagens sobre países e casos de polícia (fait divers). Procurando serem os olhos do leitor nos conteúdos e formatos noticiosos, atuavam com os princípios da fotografia humanista: não comportar a verdade, não intervir e alterar a cena, voltar a cidade para o cidadão, respeitar a si e aos outros. Como repórteres visuais da atualidade, reconstruíram uma realidade pautada no "ato de reportar":

quando me refiro ao ato de reportar, considero-o como uma manifestação do pensamento simbólico que retoma essa forma narrativa [...]. Para captar o passado, a narratividade se faz necessária no ato de reportar. Entre os diversos modos de dar significação ao vivido está este ato que, por meio das inúmeras formas de linguagem, seja na dimensão verbal ou não-verbal, toma formas e sentidos [...]. O ato de reportar faz com que um fato do mundo empírico seja re-feito pelo processo de enunciar instaurado no Sujeito dessa enunciação (TAGÉ, 2001, p. 162-163).

\section{O instante decisivo}

Henri Cartier-Bresson (1908-2004) surgiu como fotógrafo nos anos 1930. Considerado o pai da fotografia moderna e do fotojornalismo, seus flagrantes do cotidiano lidavam com situações que estavam continuamente desaparecendo. Para Cartier-Bresson, o importante era estar corporalmente disponível para ver e criar imagens. Ele tinha uma prática, a de nunca se impor ao assunto fotografado. E percorreu o mundo com a sua inseparável câmera Leica - a reconhecia como um prolongamento do olho -, sabendo o universo mais adequado para bem utilizá-la: a vida urbana, as pessoas, o lugar público, as ruas.

Lançou seu primeiro livro, Images à la Sauvette (1952), parafraseando o Cardeal de Retz (século XVII): "não há nada nesse mundo que não tenha um momento decisivo" (CARTIER-BRESSON, 1986, p. 9). O editor da Simon \& Schuster aproveitou o título da introdução de Cartier-Bresson, "L'Instant Décisif", para o título da edição americana, The Decisive Moment (1952), que se tornou a marca principal do fotógrafo. A fotografia bressoniana foi permeada pelo princípio ético de assumir a absorção de um ponto de vista entre os inúmeros possíveis. Ou seja, reconhecia o relativismo do recorte, que jamais comportaria a verdade.

O que é o "momento-decisivo"? O gesto primeiro de qualquer ação se pauta por algo invisível e drástico: uma decisão. Essa reviravolta conceitual se traduz pela prática de fixar fotograficamente, em lugar público, um instante preciso no ápice do movimento, e que nunca mais 
se repete. "Fotografar é prender sua respiração quando todas nossas faculdades convergem para captar a realidade fugidia; é então que o registro rápido dessa imagem promove grande alegria física e intelectual" (CARTIER-BRESSON, 1997, p. 24).

Cartier-Bresson percebia como seria impossível representar fotograficamente todo um eventual acontecimento para este ser compreendido. Assim buscou a síntese: registrar flagrantes fotográficos no auge do movimento. Essa noção da pintura "Gotthold-Ephraim Lessing, em seu tratado Laocoon (1766), chamava de o instante pregnante" (AUMONT, 1995, p. 231). Vale ressaltar que o instantâneo (registros em alta velocidade) havia surgido em torno de 1860. A câmera Leica, lançada no mercado em 1925, alavancou essa técnica pelo fotograma 24 $\mathrm{mm} \times 36 \mathrm{~mm}$, velocidade do obturador (1/40 s), portabilidade, precisão do aparelho e luminosidade das lentes. Mas nenhum fetiche sobre as câmeras foi sugerido pelo fotógrafo: "importante na medida em que se deve dominar a técnica para comunicar aquilo que se vê" (CARTIERBRESSON, 1986b, p. 18).

O fotógrafo francês se tornou célebre pelo "momento-decisivo" de uma imagem em preto-e-branco, que registra o perfil de um homem de chapéu, pulando sobre um espelho d'água ao lado da Gare SaintLazare (1932), na Place de l'Europe, em Paris. Salto flagrado no ar que recria, em direção contrária, o da acrobata do cartaz desenhado do circo Railowsky (colado ao muro). Na fotografia, há muitas grades e a sensação da liberdade em pleno momento histórico do entre-guerras.

O uso da câmera Leica esteve associado à fotografia de rua devido à sua facilidade de transporte e manuseio. As oportunidades e capacidades de uma Leica - em cenas espontâneas - abriram espaço para a inovação artística no fotojornalismo. Além da simplificação do filme em preto-e-branco (o uso de uma cor e a sua ausência) e da busca pelo humano, Henri Cartier-Bresson buscou a síntese imagética, isto é, o fotojornalismo sem a necessidade de legendas.

Entre a realidade e a ficção nasce o "momento-decisivo". Ao retirar imagens do real e fazer associações, surgem significados inventados pelo próprio fotógrafo, que transcendem a esfera documental. Para Cartier-Bresson não havia a preocupação com a excelência técnica: a fotografia produzida com a Leica acontecia naturalmente. Como o arqueiro zen, silencioso e desprendido de si, a vivência do momento presente era mais importante que a própria fotografia. Por outro lado, Cartier-Bresson afirmava que seu talento vinha do envolvimento pessoal com o trabalho (MOREIRA, 2007).

\section{A reportagem fotográfica}

Trazendo elementos da narrativa jornalística, Cartier-Bresson 
começou a lidar simultaneamente com o acaso, o fugidio, a organização estética, o senso de humor, o poético, a crítica, a denúncia, o lugar desprezado, o periférico do acontecimento. Essa linguagem voltou-se para o ato de fotografar sob a forma de uma reflexão despretensiosa, sendo precursora da reportagem fotográfica: produzir fatos da atualidade em visualidades sequenciais de modo não homogêneo. Ou seja, contribuiu para deixar de lado o padrão ou clichê da fotografia de imprensa, promovendo um diferencial no jornalismo visual: a fotografia informativa (e não apenas a fotografia ilustrativa, cuja legenda ainda faz indicar um caminho único de leitura).

Cartier-Bresson advertia aos fotojornalistas para chegarem respeitosamente em qualquer lugar e nunca "arrancar" imagens (contraponto ao sensacionalismo ou estilo paparazzi da imprensa contemporânea). Suas fotos eram éticas e científicas, artísticas e documentais, estéticas e informativas. Dentro de uma pauta específica, o ato fotográfico era imprevisível: seria como que "atingido" pela cena. Ele deu rosto aos personagens anônimos: homens de rua, trabalhadores, idosos, mulheres e crianças. E colocou um pouco de si a cada imagem produzida.

Ler sucessivamente as fotos de Cartier-Bresson é como olhar através de um caleidoscópio. Na criação coletiva da cidade - considerando a topologia, a ecologia, a arquitetura, os veículos, os animais, as esculturas, os graffiti, as publicidades -, o foco de sua câmera Leica era a gente, por isso a ligação natural com a narrativa jornalística. $A$ estética da vida urbana, em constante mutação, surge espontaneamente na assimetria das formas de cada lugar. É no olhar penetrante, no frescor do imediatismo e no descontínuo da linguagem fotográfica, que o "momento-decisivo" converge como foco concentrador.

Cartier-Bresson deu contribuição preciosa à reportagem fotográfica, lidando esteticamente com a justaposição de dois ou mais fragmentos (aparentemente incoerentes) em conjunto de imagens ou em fotografia única. Não por acaso, o fotógrafo francês se considerava um artesão, traçou um paralelo entre o fazer imagens e o construir belas cadeiras. Quando a oportunidade e a disponibilidade chegavam, não eram desperdiçadas: momento de apontar a câmera. "Eu não procuro jamais fazer a grande foto, é a grande foto que se oferece" (CARTIER-BRESSON, 1994).

Marcadas por uma estética de grande interesse à comunicação social, as imagens a serviço do jornalismo são também, em si, textos. $\mathrm{O}$ fotojornalismo é a prática de se valer de imagens para contar histórias. Criterioso para sensibilizar o público, complementar as informações do texto escrito, oferecer maior credibilidade à matéria - e não simplesmente 
ilustrar -, Cartier-Bresson criou um carimbo aplicado no verso de suas fotografias de imprensa: "solicito respeitar o enquadramento e as legendas" (CARTIER-BRESSON, 2004).

Fundou a agência Magnum, em 1947, juntamente com David Chim Seymour, George Rodger e Robert Capa. O pequeno grupo serviu de intermediação entre a imprensa e os fotógrafos, visando produções mais criativas e independentes. A Magnum lutou pela notícia de forma crítica e pela pauta fotográfica como possibilidade complementar à informação escrita. Além das exigências da posse dos negativos, obrigatoriedade do crédito autoral, não corte e alteração das imagens e produção da legenda pelo próprio fotógrafo. "Formamos uma cooperativa em que podíamos escolher os temas, recusando aqueles que nos propunham e não nos interessavam. Nesse sentido, não éramos mercenários" (CARTIERBRESSON, 1986, p. 122).

Cartier-Bresson reconheceu seu desejo de se igualar ou superar outrem, mas sem uma fria competição fotográfica tipo "cavalos de corrida". Como imaginar, por exemplo, naqueles tempos sem televisão, alguém documentando os últimos dias do Kuomintang, revolução chinesa em Pequim (1949), sem a companhia de outros fotógrafos? Ou fotografando Mahatma Gandhi, em Calcutá (1947), quarenta e cinco minutos antes do assassinato do líder político? "Eu espero que o aspecto aventureiro da agência Magnum exista sempre; é preciso ser aventureiro em uma atividade" (CARTIER-BRESSON, 2004).

\section{A crise da fotografia}

Baseado no argumento do fotograma como base construtiva do cinema, a fotografia se encontra numa região cinzenta entre a ficção e a realidade. Entretanto a imagem analógica representa um lugar do mundo preexistente. Para alguns autores, com o surgimento do processo digital, a fotografia analógica demarca uma espécie de fim da representação do real pelo contato direto estabelecido com a dimensão material (ROUILLÉ, 2009, p. 136).

Como repensar o ato fotográfico dentro da visão do vestígio deixado por algo? A técnica digital põe em obsolescência toda a teorização em torno do processo analógico? A consequência do surgimento da fotografia eletrônica é a crise da fotografia como documento e como "árbitro da verdade" (MACHADO, 2005, p. 312). Hoje, o ato fotográfico não mais atesta e legitima a existência de um fato pela presença do referente. Mas este princípio barthiano está na gênese da fotografia eletrônica.

A fotografia digital do objeto vassoura - podendo ser relacionada à 
calotipia "A Porta Aberta" (1843) de Henry Fox Talbot (o criador do negativo) -, não quer dizer, necessariamente, que este objeto esteve fisicamente diante da câmera. Sem discutir os limites éticos da esfera comunicacional, é possível uma manipulação quase perfeita ao real (fotografia técnica). Bem como, com menos perfeição, já eram possíveis nas outras superfícies sensibilizadas as diversas possibilidades da fotomontagem.

\section{Do documento ao monumento}

Com a técnica digital, o universo da fotografia se transforma na valorização do pragmático. Isto é, o vir a ser, o se tornar. O diferente suporte da fotografia é sinalizador do seu gênero: veículo impresso (livro, jornal, revista, cartaz), banco de imagem, exposição em galeria ou museu, álbum de família, animação (cinema, televisão, vídeo), internet (redes sociais, comunidades e websites). A mesma fotografia pode adquirir sentidos outros a depender do lugar (impresso, interativo ou multimídia) onde esteja aplicada (DUBOIS, 2009).

Isto quer dizer que opera simultaneamente com a visão de documento, ainda muito importante, e de imagem-monumento. Ou seja, a fotografia é vista como obra notável ou chocante (monumento), todavia não deixando de transmitir à posteridade informação e memória (documento). Do documento ao monumento. Ou na dialética constante entre a verdade e a ficção.

Com os meios eletrônicos há a maleabilidade (interfaces com maiores possibilidades que o meio físico), criando condições para o aumento da rapidez, alcance e interação social de fotografias. Há os bancos de imagens, afetando o fotojornalismo com preços mais acessíveis. Há as comunidades de fotografias, promovendo difusão de portfólios digitais. Há os sistemas de busca que possibilitam navegar por endereços web de fotógrafos. Tudo isso influencia a forma como a fotografia é produzida e lida.

Mudanças são sinalizadas nas práticas do fotógrafo digital em relação ao fotógrafo analógico: a visualização imediata da imagem; a não produção quadro a quadro; a não necessidade de girar o filme após o ato fotográfico; as fotos descartadas na câmera (antes eram editadas após a produção da prova contato); as telas como suporte básico (desde câmeras até computadores); o foco automático em vários lugares possíveis do enquadramento da cena; a sensibilidade (asa/iso) alterada a cada clique.

A imaterialidade do processo digital conduz a uma expansão do sentido de reconstrução da realidade, tendendo para uma representação mais abstrata, flutuante, volátil e simulada? De fato, entretanto vale sinalizar 
que para oferecer serviços na nuvem, pelo gigantismo das fazendas de servidores, as empresas de computação usam recursos com alicerces bem concretos fincados no chão. Ou seja, o termo nuvem - conceito da migração de dados digitais para pontos distantes - tem sentido ambíguo.

"Qual a intenção de se fazer imagens? E quais os sentidos que daremos às imagens?" (FONTCUBERTA, 2010). Seja na condição de fotógrafo ou leitor, as janelas estão abertas para compartilhar conhecimento interdisciplinar e confrontar pontos de vista. $\mathrm{Na}$ multiplicidade das imagens contemporâneas, a maioria produzida em forma de nuvem monolítica, surge a oportunidade de conceber textos não verbais para alavancar a condição do pixel (elemento primevo da numerização da imagem) não como "sombra petrificada", mas como mineral precioso.

\section{Considerações finais}

No tecido social urbano, caleidoscópio de imagens estimulantes, se perde comunicação aprofundada entre o drama e a alegria de viver, a denúncia social e a ecologia, a casualidade e o esperado, o bem-sucedido e a criatividade. As notícias parecem inclinadas a se guiarem quase que exclusivamente pelos interesses midiáticos do público, uma ausência do jornalismo voltado ao debate público. A superexposição apelativa da violência em lugares periféricos serve bem de exemplo. Reflexo disso é o modelo da concessão pública da comunicação social, no caso do rádio e da televisão, que não atende aos interesses da sociedade brasileira.

Ed Viggiani, fotógrafo documental premiado pela Fundação Mother Jones, reconhece a desarticulação do jornalismo visual tanto por parte dos fotojornalistas, pela competividade, quanto dos editores, pela falta de busca por conteúdo. "Nas redações dos grandes jornais e revistas noticiosos, há poucos fotógrafos contratados, como também nas sucursais não há mais repórteres fotográficos, ou seja, há pouco investimento nas reportagens" (VICGIANI, 2010).

A singularidade da profissão de fotojornalista se dilui com o advento da tecnologia digital, que democratiza a aquisição de câmeras (até integradas à telefonia celular), transformando qualquer pessoa em potencial repórter. O "momento-decisivo" bressoniano, contando com a presença do fotógrafo dentro da cena urbana, ainda pode ser considerado a referência (ou a cartilha) do fotojornalismo? Hoje, de que modo o fotojornalismo narra o cotidiano?

Sem dúvida, há ganhos. Como, por exemplo, a interação entre o fotojornalismo, a fotografia documental e a arte. Ou o criativo jogo 
informativo, principalmente na mídia impressa, entre a manchete verbal e a fotografia de capa. Ou a visão da imagem como texto. Ou mesmo o diálogo entre as linguagens verbal e não verbal. Mas qual o interesse social do fotojornalismo contemporâneo? A profissão está ameaçada?

Há portais na internet de sites para vender fotos - a busca incessante pelo furo jornalístico - para agências de fotografia e/ ou empresas de comunicação. É o "fotógrafo-cidadão", tendência do jornalismo participativo, consolidado no espaço cibernético. Em um único clique no computador, entramos em conexão com inúmeras pessoas compartilhando imagens, palavras e sons.

No jornalismo convencional, a representação especular de hoje são flores de acrílico. Sabe-se que a diluição da cultura e a pasteurização da linguagem vêm da indústria da comunicação. O repórter visual não está em busca da informação superficial. Mas na valorização do cotidiano, mantendo-se fiel ao acontecimento. É fato, a fotografia revelada no jornalismo, seja ela analógica ou digital, é frequentemente mais lembrada do que a notícia escrita.

\section{BIBLIOGRAFIA}

AUMONT, Jacques. A Imagem. Campinas: Papirus, 1995.

AVANCINI, Atílio. Atílio Avancini. Série artistas da USP n.15. São Paulo: Edusp, 2006.

Entre Gueixas e Samurais: fotografias e relatos de viagem. São Paulo: Eduspłmprensa Oficial, 2008.

BARTHES, Roland. A Câmara Clara. Lisboa: Edições 70, 1981.

O Grão da Voz. São Paulo: Martins Fontes, 2004.

Mitologias. Rio de Janeiro: Difel, 2007.

L'Obvie et L'Obtus. Paris: Éditions du Seuil, 1982.

R/B. Exposição sobre Roland Barthes no Centre Georges Pompidou (Curadoria N. Léger e M. Alphant), Paris, 2003.

Roland Barthes por Roland Barthes. São Paulo: Cultrix, 1977.

BAUMAN, Zygmunt. Modernidade Líquida. Rio de Janeiro: Jorge Zahar, 2001.

BENJAMIN, Walter. O Flâneur. In: Charles Baudelaire: um Lírico no Auge do Capitalismo. São Paulo: Brasiliense, 1991.

Pequena História da Fotografia. In: Magia e Técnica,

Arte e Política: ensaios sobre literatura e história da cultura. São Paulo: Brasiliense, 1984. 
Passagens. Belo Horizonte/São Paulo: UFMG/IOESP, 2009.

BOSI, Alfredo. Reflexões sobre a Arte. São Paulo: Ática, 2000.

CALVINO, Ítalo. A Aventura de um Fotógrafo. In:

Os Amores

Difíceis. São Paulo: Companhia das Letras, 1992.

CARTIER-BRESSON, Henri. Contacts. Documentário produzido pela La Sept/Arte e Le Centre National de la Photographie, Paris, 1994.

Henri Cartier-Bresson, Gilles Mora: Conversation. Revue Les Cahiers de La Photographie, Paris, numéro spécial à Henri CartierBresson, p. 117-125, 1986a.

Henri Cartier-Bresson, Michel Guerrin: La Photographie, une suite de coïncidences merveilleuses. Le Monde, Paris, 6 ago. 2004.

Henri Cartier-Bresson. Kyoto: Kahitsukan (Kyoto Museum of Contemporary Art), 1997.

L'Instant Décisif. Revue Les Cahiers de La Photographie, Paris, numéro spécial à Henri Cartier-Bresson, p. 9-20, 1986b.

CHÉROUX, Clément. Henri Cartier-Bresson: le tir photographique. Paris: Découvertes Gallimard, 2008.

COUCHOT, Edmond. A Tecnologia na Arte: da fotografia à realidade virtual. Porto Alegre: UFRGS, 2003.

DUBOIS, Philippe. O Ato Fotográfico e Outros Ensaios. Campinas: Papirus, 1994.

Cinema, vídeo, Godard. São Paulo: Cosac Naify, 2004.

Depoimento na Escola de Comunicações e Artes da Universidade de São Paulo, out. 2000.

Depoimento na III Semana de Fotojornalismo da ECA na Universidade de São Paulo, set. 2009.

. Depoimento na Université Sorbonne Nouvelle Paris 3, mar. 2003.

La Photo Tremblée et le Cinéma Suspendu. In: Revue La Recherche Photographique, Paris, n. 3, p. 19-27, déc. 1987.

FLÜSSER, Vilém. Filosofia da Caixa Preta. São Paulo: Hucitec, 1985.

FONTCUBERTA, Joan. El Beso de Judas: fotografía y verdad. Barcelona: G. Gili, 2000.

FONTCUBERTA, Joan. Depoimento no II Fórum Latino-Americano de Fotografia de São Paulo no Itaú Cultural, out. 2010.

FREUND, Gisèle. Photographie et Société. Paris: Seuil, 1974.

GERVAIS, Thierry. L'Illustration Photographique. Doctorat d'histoire et civilisations de École des Hautes Études en Sciences Sociales, Paris, nov. 2007.

HAVER, Gianni (org.). Photo de Presse. Lausanne: Antipodes, 2009.

LAMBERT, Frédéric. Mytographies: la photo de presse et ses légendes. 
Paris: Edilig, 1986.

LEDO, Margarita. Documentalismo Fotográfico. Madrid: Ediciones Cátedra, 1998.

LOTMAN, Yuri. Estética e semiótica do cinema. Lisboa: Estampa, 1978. MACHADO, Arlindo. A Ilusão Especular. São Paulo: Brasiliensefunarte, 1984. MACHADO, Arlindo. A Fotografia sob o Impacto da Eletrônica. In: SAMAIN, Etienne (org.). O Fotográfico. São Paulo: Hucitec/Senac, 2005. MERLEAU-PONTY, Maurice. Fenomenologia da Percepção. São Paulo: Martins Fontes, 2006.

METZ, Christian. Além da Analogia, a Imagem. In: METZ, Christian (org.). A Análise das Imagens. Petrópolis: Vozes, 1974.

MOREIRA, Carlos. Depoimento na Caixa Cultural São Paulo na exposição fotográfica "Eu olhei tanto", maio 2007.

MOREL, Gaëlle. Le Photoreportage d'auteur. Revue Études Photographiques, Paris, n. 19, déc. 2006.

PANOFSKY, Erwin. Significado nas Artes Visuais. São Paulo: Perspectiva, 1976.

PEITRARÓIA, Cristina. Questões de Leitura. São Paulo: Annablume, 2001. POIVERT, Michel. La Photographie Contemporaine. Paris: Flammarion, 2002. ROUILLÉ, André. A Fotografia: entre documento e arte contemporânea. São Paulo: Senac, 2009.

SANTAELlA, Lúcia. O que é Semiótica. São Paulo: Brasiliense, 2005.

SEKULLA, Allan. On the Invention of Photographic Meaning. In: GOLDBERG, Vicki (org.). Photography in Print. New York: Simon and Schuster, 1981.

SONTAG, Susan. Sobre Fotografia. São Paulo: Companhia das Letras, 2004. SONTAG, Susan. Diante da Dor dos Outros. São Paulo: Companhia das Letras, 2003.

TAGÉ, Terezinha (org.). Sensibilidades Configuradas: estudos sobre comunicação, mídia e produção de sentidos. São Paulo: Miró, 2009.

TAGÉ, Terezinha. Memória e Cultura no Ato de Reportar. In: Revista Fronteiras, São Leopoldo, n. 2, p. 161-172, dez. 2001.

VIGGIANI, Ed. Depoimento na IV Semana de Fotojornalismo da ECA na Universidade de São Paulo, ago. 2010. 
Atílio Avancini é fotógrafo e professor de fotojornalismo (ECA-USP). Autor dos livros Atílio Avancini - Coleção artistas da USP n. 15 (Edusp, 2006) e Entre Gueixas e Samurais: fotografias e relatos de viagem (Edusp/Imprensa Oficial, 2008). Desenvolveu aperfeiçoamento de doutorado na Université Grenoble 3 (França), em 2003. Professor visitante na Kyoto Gaidai (Japão), em 2006/2007. Fundou os Espaços D’Ávila e Milton Santos para exposições fotográficas dos alunos da USP. Responsável pela Semana de Fotojornalismo da ECA-USP. Vice-líder do grupo de pesquisa Textos da Cultura em Mídias Diferenciadas (TCULT). E-mail: avancini@usp.br 